\title{
A new marine gobiid species of the genus Clariger Jordan \& Snyder (Gobiidae,Teleostei) from Taiwan
}

\author{
Nian-Hong Jang-Liaw ${ }^{1, \dagger}$, You-Hai Gong ${ }^{1, \neq}$, I-Shiung Chen ${ }^{1,2 \S}$ \\ I Institute of Marine Biology, National Taiwan Ocean University, Keelung 20224, Taiwan, ROC 2 CMBB, \\ National Taiwan Ocean University, Keelung 20224, Taiwan, ROC \\ † urn:lsid:zoobank.org:author:C3CD61C5-A716-48B7-AFD7-9041B656CFF3 \\ ¥ urn:lsid:zoobank.org:author:B64E57AD-558E-46F3-ABF6-8C40BF9566D7 \\ § urn:lsid:zoobank.org:author:6094BBA6-5EE6-420F-BAA5-F52D44F11F14 \\ Corresponding author: I-Shiung Chen (iscfish@yahoo.com.tw; isc@ntou.edu.tw)
}

Academic editor: Carole Baldwin | Received 9 January 2012 | Accepted 19 May 2012 | Published 1 June 2012

urn:lsid:zoobank.org:pub:6EFF23CF-7041-4538-B91B-E5EFEAB63491

Citation: Jang-Liaw N-H, Gong Y-H, Chen I-S (2012) A new marine gobiid species of the genus Clariger Jordan and Snyder (Gobiidae, Teleostei) from Taiwan. ZooKeys 199: 13-21. doi: 10.3897/zookeys.199.2645

\begin{abstract}
A new species of Clariger Jordan \& Snyder, 1901 was collected from northern Taiwan. The genus was previously known only from Japanese waters. This discovery is the first formal and southernmost record of these marine gobies from the waters of subtropical Taiwan. The new species, Clariger taiwanensis $\mathbf{s p .} \mathbf{n}$., is distinguished from its congeners by a unique combination of features: (1) fin rays: dorsal-fin rays III, I/8; anal-fin rays modally I/8; and pectoral-fin rays modally $19(2+16+1)$; (2) longitudinal dermal ridge on head with 6 barbels; and (3) specific coloration pattern: head and trunk dark brown with scattered pale spots and blotches; cheek, ventral portion of head sometimes pale with deep brown spots; pectoral-fin base with a dark brown band; and caudal fin mostly dark brown proximally and with alternating and irregular dark brown and pale bands distally. A diagnostic key to all nominal species from Japan and Taiwan is provided.
\end{abstract}

\section{Keywords}

Fish fauna, fish taxonomy, marine fish, new goby, Taiwan

\section{Introduction}

The generally small body-sized gobiid fishes of the family Gobiidae constitute the most diverse group of marine teleost fishes (Miller 1988; Chen and Kottelat 2005). Within the family, the Luciogobius generic complex includes three related genera: Luciogobius

Copyright Nian-Hong Jang-Liaw et al. This is an open access article distributed under the terms of the Creative Commons Attribution License 3.0 (CC-BY), which permits unrestricted use, distribution, and reproduction in any medium, provided the original author and source are credited. 
Gill (1859), Astrabe Jordan and Snyder (1901) and Clariger Jordan and Snyder (1901), which share the following features (Akihito et al. 2000; 2002): slender to elongate body with 30 or more vertebrae in most species, a longitudinal infraorbital papillae pattern, and first dorsal fin with fewer than 4 spinous rays or first dorsal fin absent. These gobies mainly inhabit coastal waters of Japan (Akihito et al. 2000; 2002), but their ranges also extend toward Korea, eastern China, and Taiwan (Chen and Fang 1999; Akihito et al. 2000; 2002; Wu et al. 2009). Yamada et al. (2009) investigated the molecular phylogenetics of the Luciogobius generic complex based on the Japanese species and revealed the very close relationship of these three gobiid genera.

One member of the Luciogobius complex, the coastal gobiid genus Clariger, has been recognized as an endemic genus of Japan that includes at least 5 nominal species: C. cosmurus Jordan and Snyder (1901), C. exilis Snyder (1911), C. papillosus Ebina (1935), C. sirahamaensis Sakamoto (1932), C. chionomaculatus Shiogaki (1988) (Shiogaki 1988, Eschmeyer and Fricke 2011) and one undescribed species, C. sp., that was recognised in Akihito et al. (2000, 2002).

Clariger is characterized by its cylindrical body and 3-spined first dorsal fin, which separates it from Luciogobius, which lacks a first dorsal fin (Akihito et al. 1984, 2000, 2002). The major differences between Clariger and Astrabe are the following features: only 1-2 free filamentous rays on the upper part of the pectoral fin in Clariger vs. 5-6 rays in Astrabe; pectoral-fin rays $18-20$ vs. $24-27$; and a slender body profile, rather similar to that of Luciogobius, vs. robust body profile in Astrabe (Jordan and Snyder 1901, Akihito et al. 1984, 2000, 2002; Shiogaki 1988).

Recently, collections of marine gobiid fishes have been made by the National Taiwan Ocean University (NTOU) team in the coastal region of northern Taiwan. An unusual dark goby species taken in one of these surveys appears to be an undescribed species and the first appearance of the Japanese endemic genus Clariger in Taiwan. The aim of this paper is to document the first record of Clariger from Taiwan and to describe this endemic species as new to science. A diagnostic key to all 6 nominal species of Clariger including the undescribed Japanese congener from Japan and Taiwan is also provided.

\section{Materials and methods}

All type specimens of the new species were collected by hand-net. All counts and measurements were made from specimens stored in $70 \%$ ethanol after $10 \%$ formalin preservation. Morphometric methods are from Miller (1988), and meristic methods follow Akihito et al. (1984). Terminology of cephalic sensory canals and free neuromast organ (sensory papillae) is from Wongrat and Miller (1991), based on Sanzo (1911). Type specimens are deposited in the collections of National Taiwan Ocean University (NTOUP), Keelung; and National Museum of Marine Science and Technology (NMMST), Keelung.

Abbreviations: A, anal fin; C, caudal fin; D1 and D2, first and second dorsal fins, respectively; P, pectoral fin; V, pelvic fin; and VC, vertebral count. All fish lengths are standard length (SL). 


\section{Systematics}

Clariger taiwanensis sp. $\mathbf{n}$.

urn:lsid:zoobank.org:act:99B5D142-862B-4E18-959A-0A386FDEC137

http://species-id.net/wiki/Clariger_taiwanensis

Figs 1-2

Type material. Holotype: 28.3 mmSL, Taiwan, Keelung City, Chau-Jin Park, $25^{\circ} 8.48^{\prime} \mathrm{N}$, $121^{\circ} 48.140^{\prime} E$, tidal pool, 31 May 2011, Y. H. Gong (NTOUP-2011-11-062).

Paratypes: 1 specimen, $29.0 \mathrm{~mm}$ SL, same locality as holotype, 5 June 2006, I-S. Chen (NTOUP-2006-06-156). 5, 26.4-35.5 mm SL, Taiwan, New Taipei City, Yeliu, $25^{\circ} 12.08^{\prime} \mathrm{N}, 121^{\circ} 41.62^{\prime} \mathrm{E}$, tidal pool, 7 November 2000, S. C. Wang et al. (NMMSTP 01302). 1, $30.0 \mathrm{~mm} \mathrm{SL}$, same locality as holotype, 1 November 2011, Y. H. Gong (NTOUP-2011-11-057). 1, 30.9 mm SL, Taiwan, New Taipei City, Aodi, 25³.25'N, $121^{\circ} 55.81$ 'E, tidal pool, 1 July 2011, tidal pool, Y. H. Gong etal. (NTOUP-2011-11-059).

Diagnosis. Clariger taiwanensis can be distinguished from other congeners by the following unique combination of features: (1) fin rays: dorsal-fin rays III, I/8; anal-fin rays modally $\mathrm{I} / 8$; and pectoral-fin rays modally 19 ( 2 free $+16+1$ free); (2) head with longitudinal dermal ridge including 6 barbels; and (3) specific coloration pattern when alive: head and trunk dark brown with scattered pale spots and blotches; cheek, ventral portion of head sometimes pale with deep brown spots; pectoral-fin base with a dark brown band; and caudal fin mostly dark brown proximally and with alternating and irregular dark brown and pale bands distally.

Description. Body rather slender, cylindrical anteriorly and laterally compressed posteriorly (all morphometric data are shown in Table 1). Head flat and depressed. Eye small. Interorbital region wide, bony interorbital width more than twice diameter of eye. Horizontal, infraorbital dermal ridge on upper part of cheek with 6 barbels (Fig. 1).

Snout flat and rather short. A pair of distinct longitudinal dermal folds beside nasal tubes on snout. Anterior nasal opening in forward-facing short tube, and posterior nasal opening round, flat. Mouth rather large, maxilla extending to vertical through rear margin of orbit. Teeth minute, jaws with 3-5 rows of conical teeth, teeth in outer rows largest in both jaws. Tongue margin bilobed anteriorly. Gill opening somewhat restricted, extending only slightly below lower margin of pectoral-fin base. Anus located anterior to vertical through origin of second dorsal fin. VC $14+18=32$ (9 specimens). Trunk and head entirely naked.

Fins: D1 III (9 specimens); D2 I/8 (9); A I/8 (8)or I/9 (1); P $19(2+16+1)(8)$ or $20(2+17+1)(1)$. D1 very short in height and length. D2 and A of similar size and shape. A origin just in front of D2 origin. D2 origin on vertical between 1 st and 2nd branched rays of $\mathrm{A}$. P small and rounded, its length about equal to postorbital length, with 2 thin free, filamentous rays dorsally and 1 free, filamentous ray ventrally. $\mathrm{C}$ rounded. $\mathrm{V}$ with round sucking disc with complete frenum.

Head lateral-line system: Head canals: head lacking sensory canals and head pores (as for genus). Sensory papillae: all infraorbital sensory papillae arranged in longitu- 
Table I. Morphometry of Clariger taiwanensis sp. n. from Taiwan

\begin{tabular}{|c|c|c|c|c|c|}
\hline \multirow{3}{*}{$\begin{array}{l}\text { Type status } \\
\text { Sample No. }\end{array}$} & \multirow{3}{*}{$\begin{array}{c}\text { Holotype } \\
1 \\
\end{array}$} & \multicolumn{4}{|c|}{ All type specimens } \\
\hline & & \multicolumn{4}{|c|}{9} \\
\hline & & $\min$ & $\max$ & mean & $\begin{array}{l}\text { standard } \\
\text { deviation }\end{array}$ \\
\hline Total length & 34.4 & 30.3 & 41.0 & & \\
\hline Standard length & 29.3 & 26.4 & 35.5 & & \\
\hline \multicolumn{6}{|l|}{ In SL (\%) } \\
\hline Head length & 24.4 & 22.8 & 26.7 & 25.3 & 1.2 \\
\hline Snout to 1 st dorsal fin origin & 50.0 & 43.6 & 50.0 & 45.8 & 2.1 \\
\hline Snout to 2nd dorsal fin origin & 63.4 & 61.7 & 65.6 & 63.4 & 1.3 \\
\hline Snout to anus & 63.5 & 56.6 & 63.5 & 59.8 & 2.3 \\
\hline Snout to anal fin origin & 64.5 & 60.3 & 65.5 & 63.1 & 1.7 \\
\hline Caudal peduncle length & 21.8 & 20.4 & 24.2 & 21.9 & 1.4 \\
\hline Caudal peduncle depth & 9.9 & 9.9 & 12.5 & 11.1 & 0.8 \\
\hline 1st dorsal fin base & 4.0 & 4.0 & 7.1 & 5.3 & 1.0 \\
\hline 2nd dorsal fin base length & 16.6 & 15.1 & 19.0 & 16.7 & 1.3 \\
\hline Anal fin base length & 16.6 & 15.4 & 19.4 & 16.9 & 1.5 \\
\hline Caudal fin length & 19.6 & 14.7 & 19.7 & 17.1 & 1.9 \\
\hline Pectoral fin length & 13.6 & 13.1 & 16.8 & 14.6 & 1.3 \\
\hline Pelvic fin length & 9.7 & 9.7 & 12.5 & 11.2 & 1.0 \\
\hline Body depth at pelvic fin origin & 11.0 & 10.4 & 11.0 & 10.7 & 0.2 \\
\hline Body depth at anal origin & 11.5 & 11.4 & 13.5 & 12.6 & 0.8 \\
\hline Body width at anal origin & 8.5 & 8.5 & 12.2 & 10.3 & 1.1 \\
\hline Pelvic finorigin to anus & 35.2 & 30.9 & 38.0 & 33.9 & 2.2 \\
\hline Gap between bases of two dorsal fins origin & 16.5 & 16.5 & 20.3 & 18.4 & 1.3 \\
\hline \multicolumn{6}{|l|}{ In HL (\%) } \\
\hline Snout length & 23.8 & 21.3 & 25.4 & 23.5 & 1.3 \\
\hline Eye dismeter & 14.1 & 11.3 & 14.3 & 13.3 & 1.2 \\
\hline Postorbital length & 67.4 & 63.6 & 69.9 & 67.4 & 2.3 \\
\hline Interorbital width & 16.5 & 14.4 & 19.6 & 16.3 & 1.5 \\
\hline Head width & 54.1 & 54.1 & 66.0 & 58.3 & 4.0 \\
\hline Lower jaw length & 35.8 & 31.3 & 38.5 & 35.0 & 2.5 \\
\hline
\end{tabular}

dinal pattern. Row $a$ long and extending forward to below nostrils. Row $b$ extending from anterior region of dermal ridge to posterior region of cheek. Row $c$ long, running below the dermal ridge. Single $c p$ located near row $c$. Row $d$ located just above upper lip, row $d 1$ well separated from row $d$. Rows ot and oi well separated. Row $p$ surrounding orbit in interorbital region.

Colouration in fresh and preserved specimens: Head and trunk mostly dark brown with scattered pale spots and blotches when alive. Some individuals with larger pale spots in ventral half of trunk. Cheek, ventral portion of head, and underside of anterior portion of trunk sometimes pale with deep brown spots. First dorsal fin translucent 

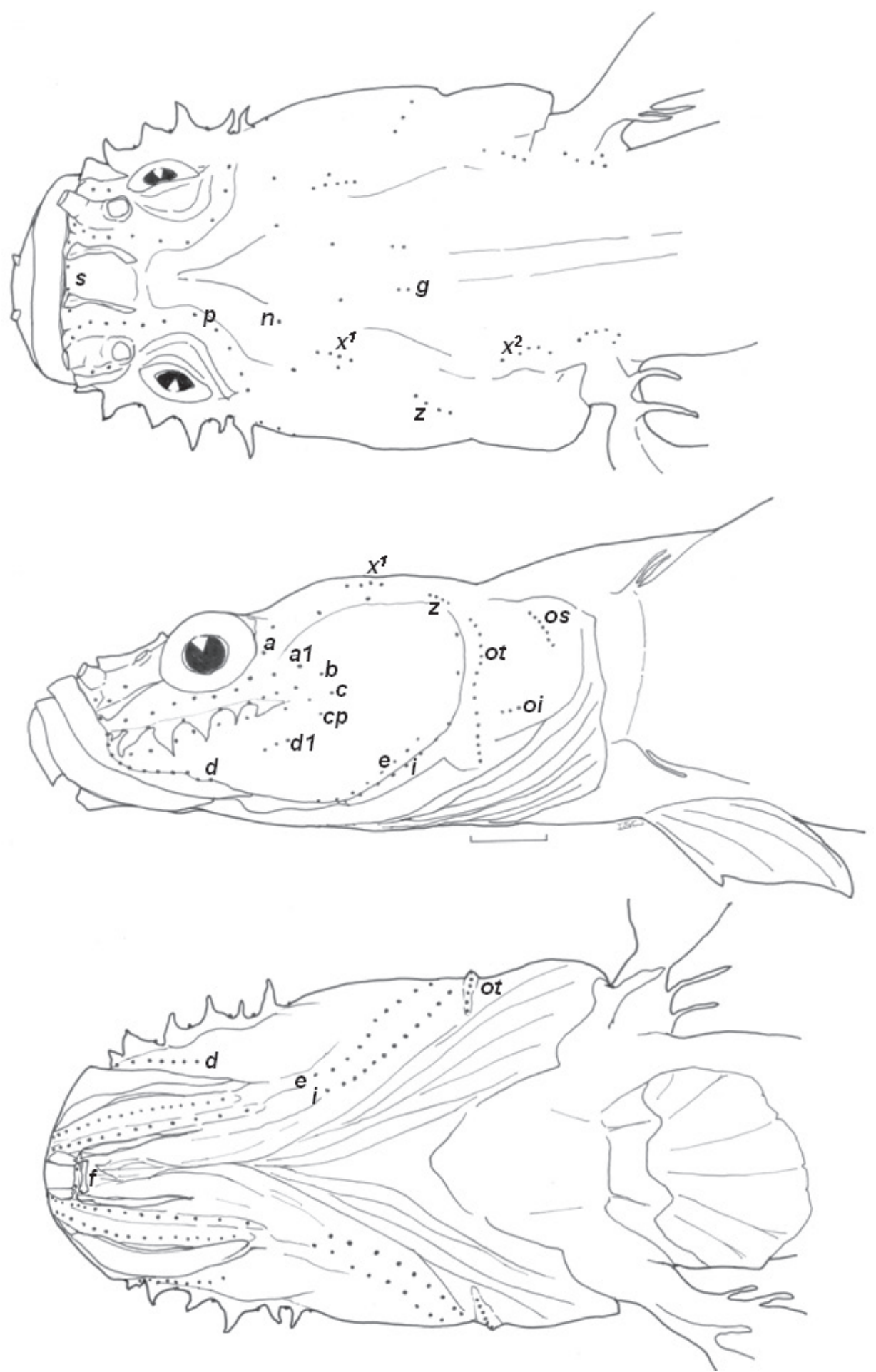

Figure I. Head lateral-line system of Clariger taiwanensis, NTOUP-2011-11-062, holotype, $28.3 \mathrm{~mm}$ SL 


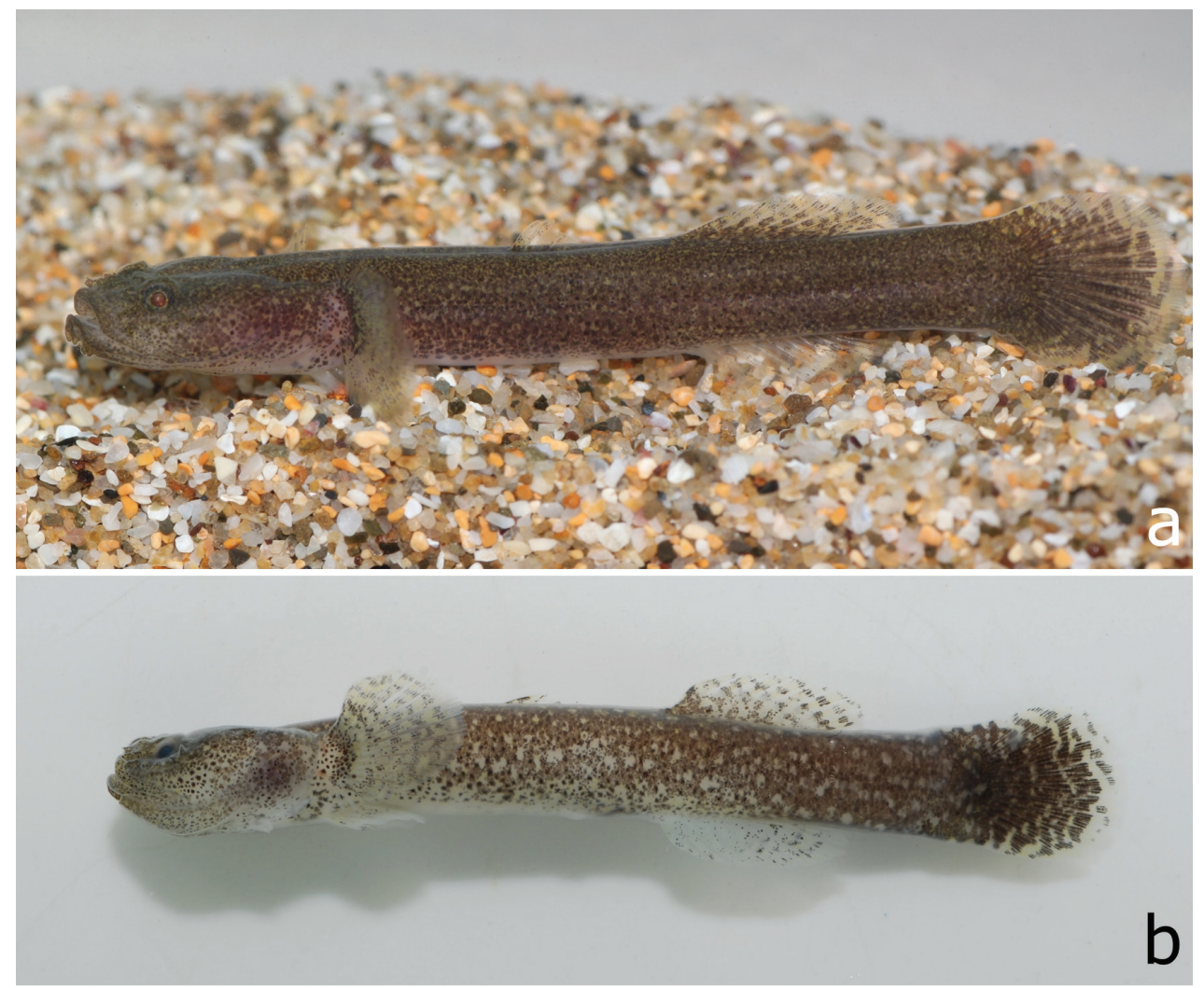

Figure 2. a A living specimen of Clariger taiwanensis sp. n., NTOUP-2011-11-057, paratype, $30.0 \mathrm{~mm}$ SL, Keelung City, Taiwan;b Formalin-fixed holotype, NTOUP-2011-062, 28.3 mm SL, Keelung City, Taiwan (Photograph by Kuan-Te Chen).

with brown dotted spinous rays. Pectoral and second dorsal fins translucent with small deep brown spots. Pectoral-fin base with a dark brown band. Anal fin translucent with a few dark brown spots mostly on the branched rays. Caudal fin mostly dark brown proximally and with alternating and irregular dark brown and pale bands distally.

Long preserved specimens with similar overall dark pattern as described above except disappearance of body pale spots.

Distribution. The new species has only been found from the coastal regions of Taipei County as well as Keelung City, Taiwan. It is highly likely that it represents an endemic marine gobiid species of Taiwan (Fig. 3).

Habitats. Clariger taiwanensis was found in tidal pools with gravel on the rocky substratum of northern coast of Taiwan. The habitat also supports other marine gobies, including several Bathygobius spp. (dominant), Eviota spp, Gobiopsis spp. and Priolepis semidoliata, as well as the Luciogobius spp.

Etymology. The specific name, taiwanensis, is in reference to the type locality from the coastal rocky shores of northern Taiwan. 


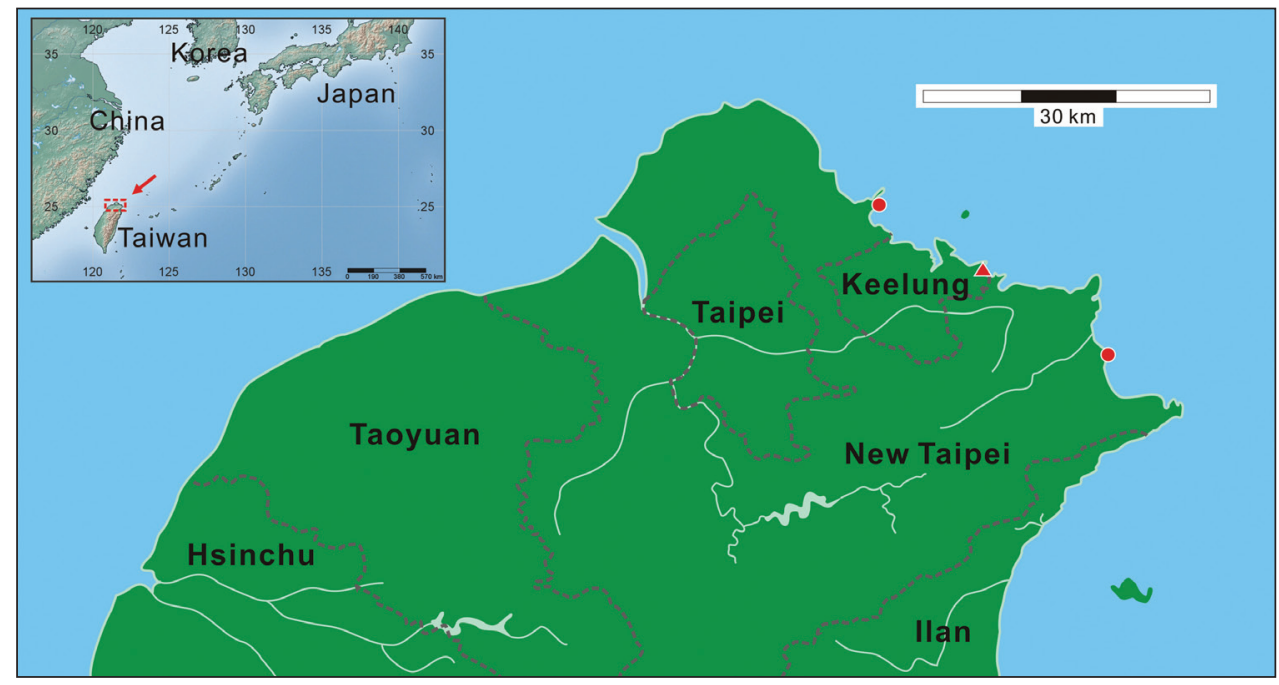

Figure 3. Map showing the collection localities (red symbols) for the Clariger taiwanensis sp. n. examined in this study in the coastal area of northern Taiwan. The red triangle shows the collection site of holotype.

Remarks. Clariger taiwanensis shares a morphological similarity (infraorbital dermal ridge with several distinct cheek barbels) with the following four species: $C$. cosmurus, C. exilis, C. papillosus, and C. chionomaculatus. Cheek barbels are lacking in C. sirahamaensis. In addition to differences in cheek barbels, the new species can be separated from C. sirahamaensis by the pattern of pigmentation on the caudal-fin: fin dark brown proximally with dark brown and pale bands distally in $C$. taiwanensis vs. fin uniform grayish black with a pair of white spots on basal regions of both upper and lower lobes in C. sirhamaensis. Clariger taiwanensis can be separated from $C$. chionomaculatus by the number of free pectoral-fin rays (2 free rays dorsally vs. 1); and coloration (no large white marks on trunk vs. several large, round white marks on upper half of trunk). Clariger taiwanensis can be distinguished from the remaining three nominal species, C. cosmurus, C. exilis, and C. papillosus by the following features: (1) fin-rays counts: second dorsal-fin rays 8 vs. 10-13 in others; anal-fin rays 8 vs. 9-11; and (2) squamation: body entirely naked vs. body scaled at least on caudal peduncle.

So far as is known, C. taiwanensis is the only species of Clariger found outside Japan, now known from the subtropical island of Taiwan. It is very essential to survey more comprehensively the coastal waters of Taiwan as well as southern China to obtain a better understanding of the species diversity, distribution, and evolutionary history of Clariger and other members of the Luciogobius complex.

\section{A diagnostic key to all nominal species of Clariger from Japan and Taiwan (adapt- ed from Shiogaki 1988 and Akihito et al. 2000, 2002):}


2a Only one free, filamentous ray on upper region of pectoral fin; anal-fin rays modally 13 ..................................................... C. chionomaculatus Shiogaki

2b Two free, filamentous rays on upper region of pectoral fin; anal-fin rays al-

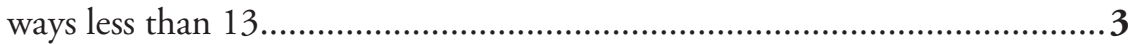

3a Body entirely naked, second dorsal-fin rays 8

C. taiwanensis Jang-Liaw, Gong \& Chen sp. n.

3b Body with small scales at least on caudal peduncle, second dorsal-fin rays

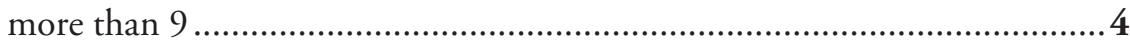

$4 a$ Gap between bases of two dorsal fins somewhat longer than body depth at anal-fin origin, head lacking distinct markings...................... exilis Snyder

4b Gap between bases of two dorsal fins less than body depth at anal-fin origin, head with a horizontal dark stripe ...............................................................

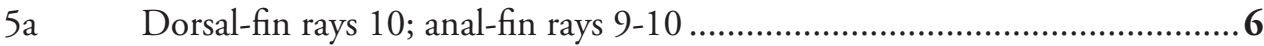

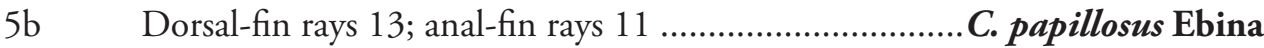

6a Dark mark extending below the dermal barbels on ridge below eye ............... C. cosmurus Jordan \& Snyder

6b No dark mark below the dermal barbels on ridge below eye ................. $\boldsymbol{C}$. sp.

\section{Acknowledgments}

The corresponding author (ISC) wishes to thank the research grant support of governmental grants from National Science Council, Taipei. The research is also partly supported from Center for Marine Bioenvironment and Biotechnology (CMBB), National Taiwan Ocean University. We are very grateful for K.T. Shao, Biodiversity Research Center, Academia Sinica and S.C. Wang, NMMST, for providing the valuable specimens for our gobioid research, and K.T. Chen, NTOU for his assistance of photograph of this goby.

\section{References}

Akihito P, Hayashi M, Yoshino T, Shimada K, Senou H, Yamamoto T (1984) Suborder Gobioidei. In: Masuda H, Amaoka K, Araga C, Uyeno T, Yoshino T (Eds) The fishes of Japanese Archipelago. Tokai University Press, Tokyo, 448 pp. [English text and plates]

Akihito SK, Ikeda Y, Sugiyama K (2000) Suborder Gobioidei. In: Nakabo T (Ed) Fishes of Japan with pictorial keys to the species. Second edition, Volume 2, Tokai University Press, Tokyo, 867-1748. [in Japanese]

Akihito SK, Ikeda Y, Sugiyama K (2002) Suborder Gobioidei. In: Nakabo T (Ed) Fishes of Japan with pictorial keys to the species. Tokai University Press, Tokyo, 867-1749.

Chen I-S, Fang LS (1999) The freshwater and estuarine fishs of Taiwan. National Museum of Marine Biology, Pingtung. [in Chinese] 
Chen I-S, Kottelat M (2005) Four new freshwater gobies of the genus Rhinogobius (Teleostei: Gobiidae) from northern Vietnam. Journal of Natural History 39: 1047-1429. doi: $10.1080 / 00222930400008736$

Ebina K (1935) Descriptions of two new fishes from Kominato, Prov. Bôsyû. Journal of the Imperial Fisheries Institute Tokyo 30(3): 211-217.

Eschmeyer WN, Fricke R (2011) Catalog of Fishes electronic version. http://research.calacademy.org/research/ichthyology/catalog/fishcatmain.asp [30 November 2011]

Gill TN (1859) Notes on a collection of Japanese fishes, made by Dr. J. Morrow. Proceedings of the Academy of Natural Sciences of Philadelphia 11: 144-150.

Jordan DS, Snyder JO (1901) A review of the gobioid fishes of Japan, with descriptions of twenty-one new species. Proceedings of the United States National Museum 24: 33-132. doi: $10.5479 /$ si.00963801.24-1244.33

Miller PJ (1988) New species of Corcyrogobius, Thorogobius, and Wheelerigobius from West Africa (Teleostei: Gobiidae). Journal of Natural History 22: 1245-1262. doi: 10.1080/00222938800770761

Sakamoto K (1932) On a collection of tide-pool fishes from Prov. Bôsyû, with a description of one new species. Journal of the Imperial Fisheries Institute 27(1): 7-13.

Sanzo L (1911) Distributione delle papille cutanee (organi ciatiform) e suo valore sistematico nei Gobi. Mitteilungen aus der Zoologishen Station zu Neapel 20: 251-238.

Shiogaki M (1988) A new gobiid fish of the genus Clariger from Mutsu Bay, northern Japan. Japanese Journal of Ichthyology 35: 127-132.

Snyder JO (1911) Descriptions of new genera and species of fishes from Japan and the Riu Kiu Islands. Proceedings of the United States National Museum 40(1836): 525-549.

Tomiyama I (1936) Gobiidae of Japan. Japanese Journal of Zoology 7(1): 37-112.

Wongrat P, Miller PJ (1991) The innervation of head neuromast rows in eleotridine gobies (Teleostei: Gobioidei). Journal of Zoology 225: 27-42. doi: 10.1111/j.14697998.1991.tb03799.x

Wu HL, Zhong JS, Chen IS (2009) Taxonomic research of the gobioid fishes (Perciformes: Gobioidei) in China. Korean Journal of Ichthyology 21: 63-72.

Yamada T, Sugiyama T, Tamaki N, Kawakita A, Kato M (2009) Adaptive radiation of gobies in the interstitial habitats of gravel beaches accompanied by body elongation and excessive vertetral segmentation. BMC Evolutionary Biology 9(145): 1-14. doi: 10.1186/1471-2148-9-145 